\title{
Retrospective Analysis of Cases with Premature Thelarche
}

\section{Prematür Telarş Tespit Edilen Kız Olguların Geriye Dönük Analizi}

\section{(D) Hasan Serdar Kıhtır1, (D) Teoman Akçay²}

${ }^{1}$ University of Health Sciences Antalya Training and Research Hospital, Clinic of Pediatric Intensive Care Unit, Antalya, Turkey

2İstinye University Medical Park Gaziosmanpaşa Hospital, Clinic of Pediatric Endocrinology and Metabolism, İstanbul, Turkey

\section{Abstract}

Objective: Premature thelarche is defined as breast enlargement in females (younger than eight years) without other signs of secondary gender character development. Although it is common in the first two years of life, it can be seen in any age group before the age of eight. In this study, girls who presented to pediatric endocrinology outpatient clinic due to early breast development were retrospectively analyzed.

Method: Patient data were analyzed retrospectively between 01.01.2011 and 31.12.2011 (one year) from pediatric endocrinology outpatient clinic files. Patients under two years of age and cases with precocious puberty were excluded from the study.

Results: Twenty-six patients with the mean age of $6.87 \pm 1.07$ years were included in the study. Premature pubarche was also present in 12 (46\%) of the cases. Height and weight standard deviations were $0.92 \pm 1$ and $1.09 \pm 0.75$, respectively. The standard deviations of body mass index were over 1 in $61.5 \%$ of the cases (16 cases). There was no correlation between the age of onset of thelarche and the age of first permanent tooth eruption and birth weight.

Conclusion: Although the etiology of premature thelarche is still unclear, there is increasing evidence that it may be associated with an increase in body fat mass.

Keywords: Obesity, premature thelarche, pubarche

\section{Öz}

Amaç: Prematür telarş 8 yaş öncesi kız çocuklarında cinsel gelişimin diğer bulguları olmaksızın görülen meme büyümesini tanımlar. İlk iki yaş arasında sık görülse de sekiz yaşına kadar her yaş grubunda görülebilir. Çalışmamızda erken meme gelişimi nedeniyle çocuk endokrinoloji polikliniğine başvuran kız olgular geriye dönük olarak incelendi.

Yöntem: Hasta verileri çocuk endokrinoloji polikliniğinin 01.01.2011 ve 31.12.2011 tarihleri arasındaki (bir yıl) dosya kayıtlarından geriye dönük olarak derlendi. İki yaş altı olgular ve puberte prekoks tespit edilen olgular çalışma dışı bırakıldı.

Bulgular: Ortalama yaşları $6,87 \pm 1,07$ yıl olan 26 olgu çalışmaya dahil edildi. Olguların 12'sinde (\%46) prematür pubarş da eşlik ediyordu. Olguların boy ve kilo standart sapmaları sırasıyla $0,92 \pm 1$ ve $1,09 \pm 0,75$ olarak tespit edildi. Olguların \%61,5'inde (16 olgu) vücut kitle indeksi standart sapması 1 'in üzerinde saptandı. Telarş başlama yaşıyla ilk kalıc diş sürme yaşı ve doğum tartısı arasında korelasyon gözlenmedi.

Sonuç: Prematür telarş etyolojisi halen net olmamakla birlikte obeziteyle ilişkili olabileceği yönünde kanıtlar artmaktadır.

Anahtar kelimeler: Obezite, prematür telarş, pubarş

\section{Introduction}

The secular trend describes the change in the physical and developmental characteristics of people over time (1). The changes in height and weight of people in the last century can also be seen in starting age of puberty in children. In a 2009 study comparing the onset of puberty, it was observed that the age of onset of puberty was shifted back, even over a 10-year period. However, there was no significant change in basal luteinizing hormone (LH) and follicle stimulating hormone (FSH) levels, but even basal estradiol (E2) levels were shown to decrease (2). Environmental factors are thought to be the largest part of this change.

Address for Correspondence: Hasan Serdar Kıhtır, University of Health Sciences Antalya Training and Research Hospital, Clinic of Pediatric Intensive Care Unit, Antalya, Turkey

E-mail: serdar.kihtir@gmail.com ORCID: orcid.org/0000-0003-0120-8711 Received: 09.03.2020 Accepted: 06.04.2020

Cite this article as: Kıhtır HS, Akçay T. Retrospective Analysis of Cases with Premature Thelarche. Bagcilar Med Bull 2020;5(2):24-27

๑C Copyright 2020 by the Health Sciences University Turkey, Bagcilar Training and Research Hospital

Bagcilar Medical Bulletin published by Galenos Publishing House. 
Isolated breast development is the most common complaint among pediatric endocrinology outpatient admissions. The definition of premature thelarche was first described by Wilkins (3) in 1957 as isolated breast development in girls before eight years of age without other physical and laboratory findings of puberty. Although it is described as a benign condition, it requires a close followup due to its potential to progress to early puberty. In this study, we aimed to define the general characteristics and personal risk factors of cases diagnosed with premature thelarche in our endocrinology outpatient clinic.

\section{Materials and Methods}

Girls who were admitted to the pediatric endocrinology outpatient clinic of Bakırköy Dr. Sadi Konuk Tranining and Research Hospital with early breast development (before eight years old) between 01.01.2011 and 31.12.2011 (one year) were investigated retrospectively. Anthropometric data, birth weight, age of first deciduous tooth, age of first permanent tooth eruption, activity status, laboratory [basal LH, FSH, E2, 17- hydroxyprogesterone, total testosterone, dehydroepiandrosterone sulfate (DHEAS)] and radiological results (bone age, uterine and ovarian measurements) were retrospectively reviewed from the endocrinology outpatient files. Cases with breast development before the age of eight years were examined for precocious puberty. Precocious puberty was considered with basal and evoked LH and FSH values, ultrasonography of uterine with long diameter greater than $35 \mathrm{~mm}$, each ovarian volume greater than $1 \mathrm{~mL}$, bone age that is two years older than calendar age or bigger than height age. Cases without precocious puberty were accepted as premature thelarche and were followed up for three-month periods without treatment. In cases with pubic or axillary hair, adrenal pathologies were excluded by DHEAS, 17-hydroxyprogesterone, total testosterone levels, and ultrasonographic evaluation of adrenal glands. Male cases, precocious puberty cases and cases under 2 years of age were not included in the study.

Ethical approval was obtained from the ethics committee of the Bakırköy Dr. Sadi Konuk Tranining and Research Hospital with the protocol number 2012/06/01 for the study. The waiver of consent was not required by the ethics committee due to the retrospective design of the study.

\section{Statistical Analysis}

Categorical data were presented as $\mathrm{n}(\%)$ and continuous data were presented as mean \pm standard deviation. The Pearson correlation analysis was used for correlation analysis. The chi-square test was used to compare categorical data. A p value of $<0.05$ was accepted for statistical significance. The Student's t-test was used to compare the difference of means and the results were expressed as the difference of means and confidence interval (CI). Statistical package for social sciences 23.0 for Windows and Medcalc 14.8.1 for Windows were used for calculations.

\section{Results}

Twenty-six cases with early breast development under the age of eight years were defined as premature thelarche (Table 1). The mean age of the patients was $6.87 \pm 1.07$ years. Standard deviations for body mass index (BMI) were found to be over 1 in 6 cases (61.5\%) and between the range of -1 and 1 in 10 cases (38.5\%). Correlation analysis was performed in all cases in relation to the age of thelarche with birth weight, age of first deciduous tooth and age of first permanent tooth eruption. There was a weak but positive correlation between the age of thelarche and the age of first deciduous tooth eruption $(\mathrm{r}=0.239, \mathrm{p}=0.018)$. There was no correlation of first permanent tooth eruption age and birth weight ( $\mathrm{r}=-0.027 \mathrm{p}=0.788, \mathrm{r}=-0.007 \mathrm{p}=0.949$ respectively) with thelarche age (birth weight: mean $3253.1 \pm 384.3 \mathrm{~g}$; first deciduous tooth eruption age: $6.5 \pm 1.2$ months). Pubic hair development (Tanner pubic stage 2) was also observed in $12(46 \%)$ of the cases. There was no statistically significant relationship between BMI standard deviation score and presence of pubic hair development $(\mathrm{p}=0.26)$. In patients with pubic hair, DHEAS levels were $77.85 \pm 36.38 \mathrm{pmol} / \mathrm{L}$,

\begin{tabular}{ll}
$\begin{array}{l}\text { Table 1. Anthropometric, laboratory and radiological data } \\
\text { of the subjects }\end{array}$ & $\begin{array}{l}\text { Mean } \pm \text { Standard } \\
\text { deviation }\end{array}$ \\
$\begin{array}{l}\text { Premature thelarche cases } \\
\mathbf{n = 2 6}\end{array}$ & $6.87 \pm 1.07$ \\
\hline The age of presentation (year) & $0.92 \pm 1$ \\
Height (standard deviation) & $1.09 \pm 0.75$ \\
Weight (standard deviation) & $1.13 \pm 0.97$ \\
Body mass index (standard deviation) & $118.33 \pm 17.06$ \\
Weight for height (\%) & $0.32 \pm 1.02$ \\
Bone age - calendar age & $0.06 \pm 0.07$ \\
Basal LH ${ }^{1}(\mathrm{IU} / \mathrm{L})$ & $1.24 \pm 0.90$ \\
Basal FSH ${ }^{2}(\mathrm{IU} / \mathrm{L})$ & $9.17 \pm 5.77$ \\
Basal E2 ${ }^{3}$ (pg/mL) & $1.2 \pm 0.64$ \\
Uterus volume $\left(\mathrm{cm}^{3}\right)$ & $22.97 \pm 4.1$ \\
Uterus height $(\mathrm{mm})$ & $1.66 \pm 1.52$ \\
\hline Total ovarian volume $\left(\mathrm{cm}^{3}\right)$ &
\end{tabular}

${ }^{1} \mathrm{LH}$ : Luteinizing hormone, ${ }^{2} \mathrm{FSH}$ : Follicle stimulating hormone, ${ }^{3} \mathrm{E} 2$ : Estradiol 
17-hydroxyprogesterone levels were $0.88 \pm 1.07 \mathrm{ng} / \mathrm{mL}$ and total testosterone levels were $0.15 \pm 0.12 \mathrm{ng} / \mathrm{mL}$. No adrenal pathology was detected in ultrasonographic imaging.

\section{Discussion}

The average onset of breast development (Tanner stage 2) in girls as described by Marshall and Tanner (4) is expected to be around $11.15 \pm 1.1$ years of age. Premature thelarche is defined as the isolated breast development in girls before eight years of age, without other findings of secondary sexual characteristics (5). It is most commonly (2.2\% - 4.7\%) seen but rarely associated with true precocious puberty before two years of age. The prevalence of premature thelarche under the age of eight in Turkey is estimated at $8.9 \%$ (6). It has been reported that $9-14 \%$ of premature thelarche cases can progress to precocious puberty (7). Although endocrine disruptive environmental factors, obesity and prematurity are frequently blamed for the development of premature thelarche, definitive factors have not been identified (8). In a study presented by Selver Eklioğlu et al. (9) in 2016, it was reported that 14 of 96 girls who were followed up for early puberty symptoms were diagnosed with premature thelarche. The age distribution of these cases was determined as mean $5.89 \pm 2.18$ years and in our study, the mean age of the cases was determined as $6.87 \pm 1.07$ years (difference of the means: $-0.98,95 \%$ CI: -2.01-0.05). In the study of Atay et al. (6), the prevalence of premature thelarche was reported to be $8.3 \%$ in Istanbul, whereas BMI standard deviation score was shown as the most important risk factor for the development of premature thelarche. It was reported that $56 \%$ of premature thelarche cases had a BMI standard deviation score above 1 and $46 \%$ had a range between 1 and -1 , and only $1.4 \%$ of cases had a BMI standard deviation score below -1. In our study, BMI standard deviation scores were above 1 in $61.5 \%$ of the cases and 2 and above in $23 \%$ of the cases. The BMI standard deviation score was not less than -1 in any case in our study. In the same study, it was stated that there was no correlation between the age of first permanent tooth eruption, prematurity, socioeconomic status and maternal menarche age with premature thelarche age. Similarly, in our study, no correlation was found between the age of first permanent tooth eruption (6.1 \pm 0.6 years) and birth weight $(3253.1 \pm 384.3 \mathrm{~g})$ and age of premature thelarche. In our study, however, a weak but significant correlation was observed between the age of the first deciduous tooth eruption and the age of premature thelarche. The role of obesity in the development of early puberty has been observed in different studies. In a meta-analysis, the risk of developing early puberty was 2.44 times higher $(95 \% \mathrm{CI}$ : 1.32-4.52) in obese girls than in non-obese subjects. In the subgroup analysis of same study, the risk of early breast development was found to be 2.03 times higher (95\% CI 1.65-2.5) in obese subjects than in non-obese subjects, but no direct correlation was found between menarche age and obesity (Relative risk: 1.38, 95\% CI: 0.76-2.49) (10).

Premature pubarche is defined as pubic or axillary hair without other signs of puberty. Although the most common cause is premature adrenarche, adrenal androgen levels can be normal. It is thought that there may be increased receptor sensitivity to normal androgen level in these cases (11). In our study, similar to the study of Atay et al. (6), there was no relationship between BMI standard deviation score and pubic hair development in premature thelarche cases.

In early-onset thelarche cases, central or peripheral early puberty should be differentiated by appropriate laboratory and radiological examinations, and cases diagnosed with premature thelarche should be followed up regularly for possible progress to early puberty (5). Although the etiologic factors are not definite in premature thelarche cases, obesity seems to be a risk factor for premature thelarche in cases under eight years of age. Therefore, studies to reduce obesity in this age group may also reduce premature thelarche cases. Although it is accepted as a benign condition, we believe that extensive research on the etiology of premature thelarche may reveal the possible causes more precisely because of its potential to progress to early puberty.

The retrospective design of the study, the small number of cases and the fact that the long-term data of the cases could not be followed are among the limitations of our study. However, it was found that the relationship between the primary tooth eruption age and premature thelarche was not studied in national and international publications. For this purpose, it is important to support the relationship with advanced, multicenter studies in terms of cause and effect and follow-up of pediatric cases.

\section{Ethics}

Ethics Committee Approval: Ethical approval was obtained from the ethics committee of the Dr. Sadi Konuk Training and Resarch Hospital with the protocol number 2012/06/01 for the study.

Informed Consent: Patient consent could not be obtained because it was a retrospective study.

Peer-review: Externally peer-reviewed. 


\section{Authorship Contributions}

Concept: H.S.K., T.A., Design: H.S.K., T.A., Data Collection or Processing: H.S.K., T.A., Analysis or Interpretation: H.S.K., T.A., Literature Search: H.S.K., T.A., Writing: H.S.K., T.A.

Conflict of Interest: No conflict of interest was declared by the authors.

Financial Disclosure: The authors declared that this study has received no financial support.

\section{References}

1. Özer BK. Secular Changes in Height and Leg Length Among Turkish Children During the last century. Ankara Üniversitesi Dil ve Tarih-Coğrafya Fakültesi Derg 2007;47(1):95-113.

2. Aksglaede L, Sørensen K, Petersen JH, Skakkebaek NE, Juul A. Recent decline in age at breast development: the Copenhagen Puberty Study. Pediatrics 2009;123(5):e932-e939.

3. Wilkins L. The Diagnosis and Treatment of Endocrine Disorders of Childhood and Adolescence. Arch Dis Child 1958;33(168):184.

4. Marshall WA, Tanner JM. Variations in pattern of pubertal changes in girls. Arch Dis Child 1969;44(235):291-303.
5. Khokhar A, Mojica A. Premature Thelarche. Pediatr Ann 2018;47(1):e12-e15.

6. Atay Z, Turan S, Guran T, Furman A, Bereket A. The prevalence and risk factors of premature thelarche and pubarche in 4- to 8-yearold girls. Acta Paediatr 2012;101(2):e71-e75.

7. Pasquino AM, Pucarelli I, Passeri F, Segni M, Mancini MA, Municchi G. Progression of premature thelarche to central precocious puberty. J Pediatr 1995;126(1):11-14.

8. Chiabotto P, Costante L, de Sanctis C. Premature thelarche and environmental pollutants. Minerva Med 2006;97(3):277-285.

9. Selver Eklioğlu B, Atabek ME, Akyürek N, Sarikaya E. The Etiologic Distribution and Clinical Features of Cases Presenting with the Findings of Puberty to the Pediatric Endocrinology Clinic. Turkish J Pediatr Dis 2016;10(4)-233-236.

10. Li W, Liu Q, Deng X, Chen Y, Liu S, Story M. Association between Obesity and Puberty Timing: A Systematic Review and MetaAnalysis. Int J Environ Res Public Health 2017;14(10):1266.

11. Vottero A, Capelletti M, Giuliodori S, Viani I, Ziveri M, Neri TM, et al. Decreased androgen receptor gene methylation inpremature pubarche: a novel pathogenetic mechanism? J Clin Endocrinol Metab 2006;91(3):968-972. 